\title{
PENGARUH SERVICE QUALITY DAN CUSTOMER TRUST TERHADAP CUSTOMER SATISFACTION SERTA DAMPAKNYA PADA CUSTOMER LOYALTY PERBANKAN SYARIAH
}

\author{
Zahriatul 'Aini \\ Program Studi Administrasi Perkantoran Politeknik Kutaraja
}

\begin{abstract}
Abstrak
Tujuan penelitian ini adalah untuk mengetahui: (1) tentang service quality,customertrust,customer satisfactiondancustomer loyaltypada Bank Syariah di Kota Banda Aceh (2) pengaruh service quality terhadap customer satisfaction, (3) pengaruh customertrust terhadap customer satisfaction (4) pengaruh service quality terhadap customer loyalty(5) pengaruh customertrust terhadap customer loyalty, (6) pengaruh customer satisfactionterhadap customer loyaltydan (7) terdapat pengaruh tidak langsung service quality dan customertrust terhadap customer loyaltymelaluicustomer satisfactionnasabah pada Bank Syariah di Kota Banda Aceh. Penelitian ini dilakukan pada Bank Syariah di Kota Banda Aceh. Adapun yang menjadi objek penelitian ini adalah service quality dan customer trust,customer satisfactiondancustomerloyaltyBank Syariah di Kota Banda Aceh.Hasil penelitian menunjukkan bahwa service quality, custumer trust, customer satisfaction dan customer loyalty pada Bank Syariah di Kota Banda Aceh sudah relatif baik, service qualitymempunyai berpengaruh terhadap customer satisfaction, custumer trust berpengaruh terhadap customer satisfaction, service quality berpengaruh terhadap customer loyalty, custumer trust berpengaruh signifikan terhadap customer loyalty dan terdapat pengaruh customer satisfactionterhadap customer loyalty serta terdapat pengaruh direct dan indirectservice quality, custumer trust terhadap customer satisfaction dan berdampak terhadapcustomer loyalty pada Bank Syariah di Kota Banda Aceh.
\end{abstract}

Kata Kunci: service quality, customer trust, customer satisfaction dan customer loyalty

\section{PENDAHULUAN}

Kepuasan pelanggan merupakan salah satu faktor yang dapat mempengaruhi terhadap tingkat loyalitas nasabah perbankan dalam menggunakan jasa pelayanan yang diberikan oleh pihak bank syariah kepada nasabahnya. Fakta dari masih rendahnya kepuasan nasabah dapat dilihat dari tingkat pelayanan yang diterima masih belum dapat memuaskan nasabah, seperti nasabah harus antri pada teller maupun customer service dengan waktu yang lama, sehingga menimbulkan kebosanan maupun ketidakpercayaan nasabah terhadap produk bank syariah yang masih dianggap sama dengan produk bank konvensional.

Namun rendahnya kepuasan pelanggan akan memberikan dampak yang positif bagi penurunan loyalitas nasabah dalam menggunakan jasa pelayanan yang diberikan. Rendahnya kepuasan pelanggan salah satunya disebabkan oleh kualitas pelayanan yang diberikan oleh institusi perbankan syariah di Kota Banda Aceh yang masih kurang memuaskan bagi para nasabahnya atau pelayanan yang diberikan masih relatif rendah. Hal ini dapat dilihat dari tingkat perpindahan nasabah dari bank syariah ke bank konvensional yang masih tinggi atau 
nasabah yang masih mempunyai rekening ganda antara rekening perbankan syariah dan perbankan konvensional.

Persaingan dalam bisnis perbankan semakin ketat sehingga mendorong para pelaku bisnis untuk menciptakan atau menyediakan produk-produk yang inovatif sehingga dapat memberikan kemudahan bagi para pelanggannya. Dukungan teknologi menjadi pilihan yang tak terelakkan untuk digunakan agar penciptaan produk yang bermutu, pelayanan yang baik dan kemudahan bagi pelanggan dapat diwujudkan, bahkan penerapan teknologi informasi menjadi salah satu faktor penentu keunggulan kompetitif dalam persaingan bisnis yang semakin tajam dan cenderung berorientasi pada customer value.

Dalam dunia jasa pelayanan, perbankan akan selalu dihadapkan pada berbagai permasalahan yang harus dihadapi, diantaranya seperti tingkat kepercayaan nasabah (trust), kepuasan nasabah (satisfaction), dan peningkatan kualitas pelayanan. Dharmayanti (2006), menjelaskan bahwa permasalahan yang mungkin muncul dalam jasa pelayanan adalah permasalahan yang berkaitan dengan ketiga hal tersebut atau variasi dari ketiganya atau permasalahan lainnya yang mungkin muncul dengan karakteristik yang bervariasi dan berbedabeda. Kemudian mereka juga menjelaskan bahwa diantara satu perusahaan dengan perusahaan lainnya permasalahan yang muncul belum tentu sama (bervariasi), misalnya jika dilihat dari kinerja para karyawan, belum tentu penilaian kinerja di restoran fast food akan sama dengan di perusahaan asuransi atau perbankan.

Kemajuan perekonomian masyarakat khususnya di Kota Banda Aceh juga turut mempengaruhi masyarakat sebagai nasabah dalam memanfaatkan jasa fasilitas perbankan. Peningkatan status sosial dan ekonomi masyarakat berakibat pada perubahan perilaku dan gaya hidup mereka. Perubahan tersebut pada akhirnya mempengaruhi selera kepuasan terhadap suatu produk. Agar dapat bersaing dan bertahan hidup bank dituntut untuk mempunyai citra dan pelayanan yang baik yang dapat memenuhi kebutuhan dan keinginan pelanggan. Supriyanto (2015 : 40) menyatakan bahwa kinerja perusahaan tidak cukup hanya diukur berdasarkan laba akuntansi saja, karena laba akuntansi tidak mempunyai makna riil apabila apabila tidak didukung oleh kemampuan perusahaan dalam meningkatkan nilai tambah secara ekonomis. Bank Syariah sebagai perusahaan jasa perbankan yang didasarkan pada hukum Islam tidak akan mungkin menghindar dari persaingan industri perbankan yang semakin meningkat.

Fenomena yang melatarbelakangi penelitian ini adalah masih rendahnya loyalitas nasabah dalam menggunakan jasa Bank Syariah di Kota Banda Aceh. Hal ini dapat dilihat tidak konsistennya sebagian dari nasabah yang masih suka berpindah dari satu pelayanan bank 
dengan pelayanan bank lainnya. Rendahnya loyalitas nasabah ini dipicu oleh masih rendahnya kualitas pelayanan yang diberikan oleh pihak perbankan syariah di Kota Banda Aceh terutama masih lambat dalam memberikan pelayanan kepada nasabah maupun tingkat kepercayaan masyarakat atau nasabah yang masih rendah terhadap peran bank syariah dalam memasarkan produk perbankan. Selain itu masih rendahnya loyalitas nasabah juga dipengaruhi oleh tingkat kepuasan nasabah yang masih dibawah harapan yang diberikan oleh pihak perbankan syariah di Kota Banda Aceh. Rendahnya kepuasan nasabah dapat dilihat dari pelayanan yang diberikan oleh pihak bank syariah, kualitas produk yang dianggap masih sama dengan produk bank konvensional maupun faktor kenyamanan dan keamanan saat bertransaksi di Bank Syariah.

Fenomena mengenai loyalitas nasabah yang terjadi pada perbankan syariah di Banda Aceh, berdasarkan hasil wawancara terhadap 20 orang nasabah yang memiliki tabungan pada bank syariah di Kota Banda Aceh sebagian besar nasabah tidak loyal pada banknya. Dari 15 nasabah atau 70\% nasabah mengaku tidak loyal kepada banknya dikarenakan lambatnya penanganan transaksi yang dilakukan pihak bank, selanjutnya 5 nasabah lainnya (30\%) mengungkapkan alasan ketidakloyalitasnya mereka kepada bank ditempat mereka menabung adalah karena lingkungan yang tidak nyaman, dan pihak bank yang hanya menganggap hubungan terhadap nasabah hanya sebatas kreditur dan debitur.

\section{TINJAUAN PUSTAKA}

\section{Loyalitas Konsumen}

Saat ini, iklim kompetisi dalam dunia perdagangan semakin terasa. Di sisi lain perubahan lingkungan yang demikian pesat semakin mendukung kompetisi yang sedang terjadi saat ini. Menurut Dick dan Basu (2004), salah satu tujuan utama aktivitas pemasaran seringkali dilihat dari pencapaian loyalitas pelanggan melalui strategi pemasaran (Siregar, 2004). Loyalitas pelanggan merupakan bagian terpenting pada pengulangan pembelian pada pelanggan (Caruana, 2006).

Menurut Reichheld dan Sasser (2007), loyalitas pelanggan memiliki korelasi yang positif dengan performa bisnis (Beerli dkk., 2004). Menurut Castro dan Armario (2009), loyalitas pelang-gan tidak hanya meningkatkan nilai dalam bisnis, tetapi juga dapat menarik pelanggan baru (Beerli dkk., 2004). Pada jangka pendek, memperbaiki loyalitas pelanggan akan membawa profit pada penjualan. Profit merupakan motif utama konsistensi bisnis, karena dengan keuntungan maka roda perputaran bisnis dari variasi produk dan jasa yang ditawarkan maupun perluasan pasar yang dilayani (Soeling, 2007). 
Kemudian menurut Kotler (2007 : 231), menyebutkan bahwa loyalitas konsumen secara umum dapat diartikan kesetiaan seseorang atas sesuatu produk, baik barang maupun jasa tertentu. Loyalitas konsumen merupakan manifestasi dan kelanjutan dari kepuasan konsumen dalam menggunakan fasilitas maupun jasa pelayanan yang diberikan oleh pihak perusahaan, serta untuk tetap menjadi konsumen dari perusahaan tersebut.

Lebih lanjut disebutkan bahwa loyalitas adalah bukti konsumen yang selalu menjadi konsumen, yang memiliki kekuatan dan sikap positif atas perusahaan itu. Kesetiaan konsumen terhadap suatu barang atau jasa merek tertentu tergantung pada beberapa faktor : besarnya biaya untuk berpindah ke merek barang atau jasa yang lain, adanya kesamaan mutu, kualitas atau pelayanan dari jenis barang atau jasa pengganti, adanya resiko perubahan biaya akibat barang atau jasa pengganti dan berubahnya tingkat kepuasan yang didapat dari merek baru dibanding dengan pengalaman terhadap merek sebelumnya yang pernah dipakai.

\section{Kepuasan Pelanggan}

Secara linguistik, Satisfaction berasal dari bahasa latin yaitu satis yang berarti cukup dan facere melakukan atau membuat. Berdasarkan pendekatan linguistik ini maka kepuasan dapat diartikan bahwa produk atau jasa yang mampu memberikan lebih dari pada yang diharapkan konsumen.

Kepuasan Konsumen adalah kondisi dimana harapan konsumen mampu dipenuhi oleh produk (Kotler \& Armstrong, 2007). Konsumen memberikan respon tertentu sebagai hasil evaluasinya terhadap kesenjangan antara harapannya dengan kinerja produk. Oliver (2005) berpendapat bahwa Kepuasan Konsumen merupakan penilaian konsumen terhadap fitur-fitur produk atau jasa yang berhasil memberikan pemenuhan kebutuhan pada level yang menyenangkan baik itu dibawah maupun diatas harapan. Dengan kata lain dalam pandangan Oliver fitur produk berperan penting dalam penciptaan kepuasan konsumen. Jadi, tingkat kepuasan konsumen merupakan fungsi dari perbedaan antara kinerja yang dirasakan dengan harapan apabila kinerja di bawah harapan maka konsumen akan puas serta bila kinerja melebihi dari harapan konsumen akan merasa sangat puas.

Konsep berpikir bahwa kepuasan konsumen akan mendorong meningkatnya profit adalah bahwa konsumen yang puas akan bersedia membayar lebih untuk "produk" yang diterima dan lebih bersifat toleran akan kenaikan harga. Hal ini tentunya akan meningkatkan margin perusahaan dan kesetiaan konsumen pada perusahaan. Konsumen yang puas akan membeli "produk" lain yang dijual oleh perusahaan, sekaligus menjadi "pemasar" yang efektif melalui Word of mouth yang bernada positif. Hal ini dapat membantu meningkatkan penjualan dan 
kredibilitas perusahaan, namun perlu diingat bahwa ternyata peningkatan market share tidak selamanya sesuai dengan peningkatan kepuasan konsumen, bahkan dalam banyak hal atau kasus yang terjadi adalah justru kebalikannya, semakin besar market share sebuah perusahaan justru kepuasan konsumen semakin menurun.

\section{Kualitas Pelayanan Perbankan}

Menurut Kotler dan Keller (2010) menyatakan bahwa pelayanan atau jasa merupakan setiap tindakan atau kegiatan yang dapat ditawarkan oleh satu pihak kepada pihak lain, pada dasarnya tidak berwujud dan tidak mengakibatkan kepemilikan apapun.

Pelayanan sering sekali terkait dengan unsur jasa sehingga sering pula disebut sebagai jasa pelayanan. Jasa yang dimaksud adalah jasa yang ditawarkan perusahaan pihak perbankan dalam usaha menarik konsumen melalui pemberian pelayanan maksimal bagi konsumen pengguna jasa dari pelayanan itu sendiri.

Modernitas dengan kemajuan teknologi akan mengakibatkan persaingan yang sangat ketat untuk memperoleh dan mempertahankan pelanggan. Kualitas pelayanan menjadi suatu keharusan yang harus dilakukan perusahaan supaya mampu bertahan dan tetap mendapat kepercayaan pelanggan. Pola konsumsi dan gaya hidup pelanggan menuntut perusahaan mampu memberikan pelayanan yang berkualitas. Keberhasilan perusahaan dalam memberikan pelayanan yang berkualitas dapat ditentukan dengan pendekatan service quality yang telah dikembangkan oleh Parasuraman, Berry dan Zenthaml (dalam Lupiyoadi,2006: 181).

Kualitas pelayananadalah seberapa jauh perbedaan antara harapan dan kenyataan para pelanggan atas layanan yang mereka terima. Service Quality dapat diketahui dengan cara membandingkan persepsi pelanggan atas layanan yang benar-benar mereka terima dengan layanan sesungguhnya yang mereka harapkan. Kualitas pelayanan menjadi hal utama yang diperhatikan serius oleh perusahaan, yang melibatkan seluruh sumber daya yang dimiliki perusahaan.

\section{Kepercayaan Konsumen}

Pemahaman yang lengkap tentang keputusan konsumen tidak dapat diperoleh tanpa penjelasan mengenai kepercayaan terhadap merek (trust in a brand) dan bagaimana hubungannya dengan keputusan pemilihan perbankan. Dalam pemasaran industri, para peneliti telah menemukan bahwa kepercayaan terhadap sales dan supplier merupakan sumber dari keputusan seseorang untuk melakukan pembelian.

Menurut Lau dan Lee (1999: 44 ), terdapat tiga faktor yang mempengaruhi kepercayaan terhadap merek. Ketiga faktor ini berhubungan dengan tiga entitas yang tercakup dalam 


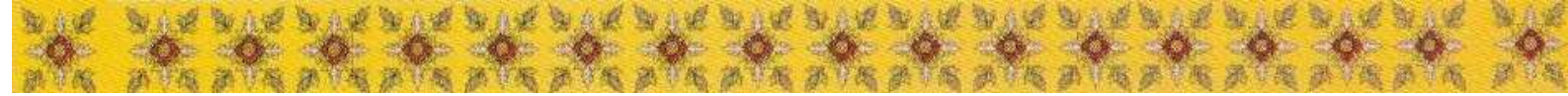

hubungan antara merek dan konsumen. Adapun ketiga faktor tersebut adalah merek itu sendiri, perusahaan pembuat merek, dan konsumen.

Kemudian Soderlund dan Julander (2003) menjelaskan bahwa kepercayaan nasabah dapat dikaitkan dengan kinerja dari perusahaan. Dan mereka melihat kinerja tersebut berdasarkan tingkat keberhasilan pelayanan yang mampu diberikan oleh suatu perusahaan, karena mereka berpendapat bahwa produk yang sama namun jika dibeli ditempat yang berbeda pasti akan mendapatkan pelayanan yang berbeda. Dengan demikian kesenjangan yang mereka (konsumen) rasakan (kesenjangan antara yang diharapkan dengan yang didapatkan atau diperoleh) itulah yang sering disebut dengan kepuasan.

\section{METODE PENELITIAN}

\section{Lokasi dan Objek Penelitian}

Penelitian ini dilakukan pada nasabah Bank Syariah di Kota Banda Aceh. Objek penelitian ini berkaitan dengan service quality dan customer trust,customer satisfaction dan customerloyalty.

\section{Populasi dan Sampel}

Populasi dalam penelitian ini adalah seluruh nasabah Bank Syariah di Kota Banda Aceh. Pengambilan sampel dilakukan dengan teknik probability sampling terhadap setiap nasabah pada Bank Syariah di Kota Banda Aceh. Menurut Arikunto (2002 : 108) populasi adalah keseluruhan subjek penelitian. Populasi yang dimaksud dalam penelitian ini adalah seluruh nasabah pada Bank Syariah di Kota Banda Aceh. Dalam penelitian ini Bank Syariah yang beroperasi di Kota Banda Aceh sebanyak 8 kantor Bank Syariah, dan agar semua nasabah mendapatkan kesempatan yang sama untuk menjadi responden, maka penulis telah menetapkan jumlah responden dalam penelitian ini sebanyak 160 orang yang terbagi untuk masing-masing nasabah yaitu sebanyak 20 orang, agar tidak menimbulkan gap (perbedaan) persepsi antara nasabah bank syariah lainnya..

\section{Peralatan Analisis Data}

Suatu penelitian membutuhkan analisis data dan interpretasinya yang bertujuan menjawab pertanyaan-pertanyaan peneliti dalam rangka mengungakap fenomena sosial tertentu. Analisis data adalah proses penyederhanaan data ke dalam bentuk yang lebih mudah dibaca dan dinterpretasikan. Metode yang dipilih untuk analisis data harus sesuai dengan pola penelitian dan variabel yang akan diteliti, (Ferdinand, 2000). 


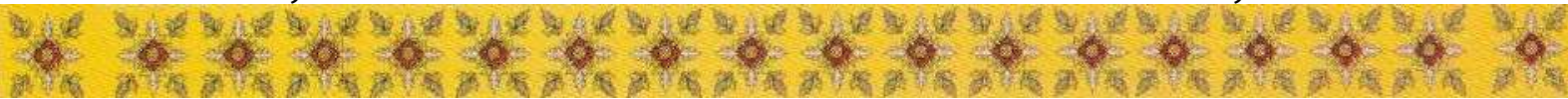

Model yang digunakan dalam penelitian ini adalah model kausalitas (sebab akibat) yang digunakan hubungan dan pengaruh antara variabel bebas dengan variabel tergantungnya, serta faktor-faktor didalamnya. Untuk menganalisis data digunakan The Structural Equation Modelling (SEM) dengan menggunakan program AMOS. Permodelan dengan SEM memungkinkan dijawabnya pertanyaan penelitian secara dimensional, (Ferdinand, 2000).

Model persamaan struktural (SEM) adalah sekumpulan teknik-teknik statistikal yang memungkinkan pengujian sebuah rangkaian hubungan relatif murni "rumit" secara simultan (Ferdinand, 2000). Keunggulan aplikasi SEM dalam penelitian manajemen adalah karena kemampuannya untuk mengkonfirmasi dimensi-dimensi dari sebuah konsep atau faktor yang sangat lazim digunakan dalam manajemen serta kemampuannya untuk mengukur pengaruh hubungan-hubungan yang secara teoritis ada.

\section{HASIL ANALISIS}

\section{Analisis Structural Equation Modelling (SEM)}

Analisis Structural Equation Model (SEM) secara full model, dilakukan untuk mengetahui tingkat unidimensionalitas dari indikator-indikator pembentuk variabel laten yang diuji dengan confirmatory factor analysis. Analisis hasil pengolahan data pada tahap full model SEM dilakukan dengan melakukan uji kesesuaian dan uji statistik. Hasil pengolahan data untuk analisis full model SEM ditampilkan pada Gambar 1.

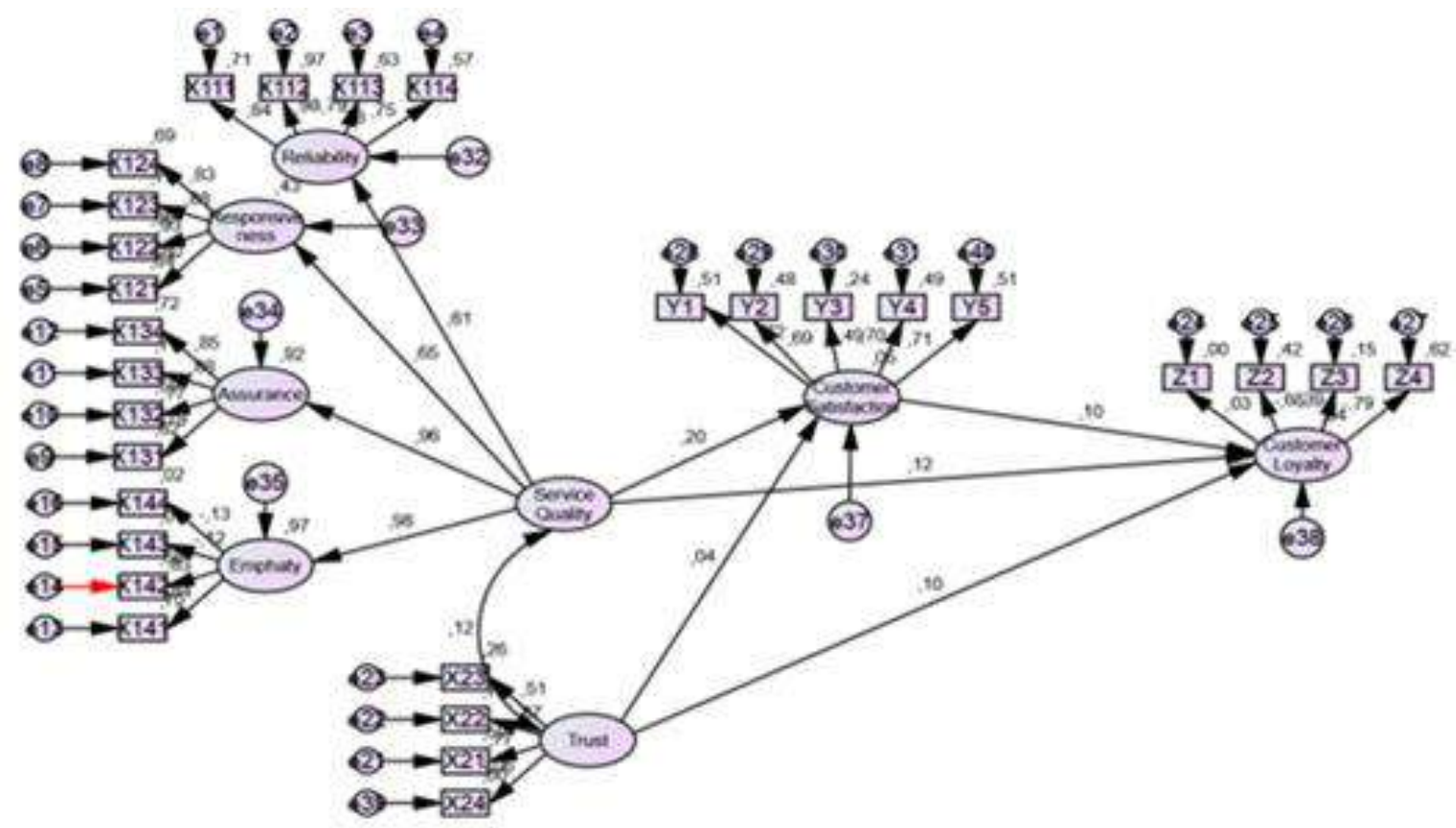

Gambar 1 Structural Equation Model 


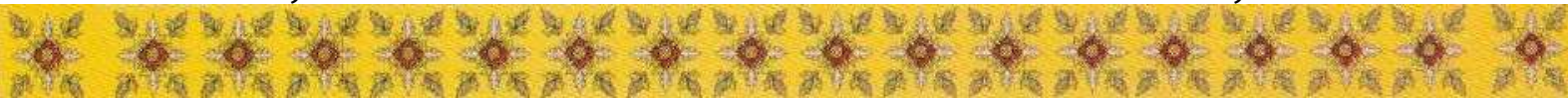

Pengaruh Service Quality Terhadap Customer Satisfaction Pada Bank Syariah di Kota Banda Aceh

Parameter estimasi untuk pengujian pengaruh service quality terhadap customer satisfaction menunjukkan nilai CR sebesar 2,172 dan dengan probabilitas sebesar 0,030. Kedua nilai yang diperoleh tersebut memenuhi syarat untuk penerimaan H1 yaitu nilai CR sebesar 2,172 yang lebih besar dari 1,97 dan probabilitas yang lebih kecil dari 0,05.

Pengaruh Customer Trust Terhadap Customer Satisfaction pada Bank Syariah di Kota Banda Aceh

Parameter estimasi untuk pengujian pengaruh customer trust terhadap customer satisfaction menunjukkan nilai CR sebesar 2,395 dan dengan probabilitas sebesar 0,043. Kedua nilai tersebut diperoleh memenuhi syarat untuk penerimaan H2 yaitu nilai CR sebesar 2,395 yang lebih besar dari 1,97 dan probabilitas yang lebih kecil dari 0,05.

Pengaruh Customer Satisfaction Terhadap Customer Loyalty Pada Bank Syariah di Kota Banda Aceh

Parameter estimasi untuk pengujian pengaruh customer satisfaction terhadap customer loyalty menunjukkan nilai CR sebesar 2,954 dan dengan probabilitas sebesar 0,040. Kedua nilai tersebut diperoleh memenuhi syarat untuk penerimaan H2 yaitu nilai CR sebesar 2,954 yang lebih besar dari 1,97 dan probabilitas yang lebih kecil dari 0,05.

Pengaruh Service Quality Terhadap Customer Loyalty Pada Bank Syariah di Kota Banda Aceh

Parameter estimasi untuk pengujian pengaruh service quality terhadap customer loyalty menunjukkan nilai CR sebesar 2,231 dan dengan probabilitas sebesar 0,018. Kedua nilai tersebut diperoleh memenuhi syarat untuk penerimaan H4 yaitu nilai CR sebesar 2,231 yang lebih besar dari 1,97 dan probabilitas yang lebih kecil dari 0,05.

\section{Pengaruh Customer Trust Terhadap Customer Loyalty Pada Bank Syariah di Kota Banda} Aceh

Parameter estimasi untuk pengujian pengaruh komnikasi terhadap customer loyalty menunjukkan nilai CR sebesar 2,163 dan dengan probabilitas sebesar 0,046. Kedua nilai tersebut memenuhi syarat untuk penerimaan H5 yaitu nilai CR sebesar 2,163 yang lebih besar dari 1,97 dan probabilitas yang lebih kecil dari 0,05.

\section{Analisis Pengaruh Tidak Langsung}

Pengaruh langsung variabel service quality terhadap customer loyalty adalah 0,238. Sementara pengaruh service quality terhadap customer loyalty bila melalui variabel customer satisfaction adalah 0,000048. Ini berarti bila ingin meningkatkan customer loyalty oleh Bank 
Syariah di Kota Banda Aceh, maka akan lebih baik bila pihak bank langsung meningkatkan kualitas pelayanan perbankan dengan cara menyediakan berbagai fasilitas dan kemudahan bagi setiap nasabah.

Pengaruh langsung variabel customer trust terhadap customer loyalty adalah 0,04. Sementara pengaruh customer trust terhadap customer loyalty bila melalui variabel customer satisfaction adalah 0,000036. Ini berarti bila ingin meningkatkan customer loyalty oleh pada perbankan syariah di Kota Banda Aceh, maka akan lebih baik bila pihak Bank Syariah di Banda Aceh langsung memperbaiki citra bank sehingga meningkatkan kepercayaan konsumen sehingga akan memberikan dampak terhadap loyalitas konsumen dalam menggunakan jasa pelayanan Bank Syariah di Kota Banda Aceh.

\section{KESIMPULAN}

Berdasarkan hasil penelitian, maka peneliti dapat menyimpulkan beberapa kesimpulan diantaranya yaitu:

1. Hasil penelitian secara deskriptif menunjukkan bahwa service quality, custumer trust, customer satisfaction dan customer loyalty pada Bank Syariah di Kota Banda Aceh sudah relatif baik, hal ini mengindikasikan bahwa semua variabel dipersepsikan secara lebih baik oleh nasabah.

2. Hasil penelitian untuk hipotesis pertama diperoleh penjelasan bahwa service quality berpengaruh terhadap customer satisfaction pada Bank Syariah di Kota Banda Aceh.

3. Hasil penelitian untuk hipotesis kedua diperoleh penjelasan bahwa custumer trust berpengaruh terhadap customer satisfaction pada Bank Syariah di Kota Banda Aceh.

4. Hasil penelitian untuk hipotesis ketiga diperoleh penjelasan bahwa service quality berpengaruh terhadap customer loyalty pada Bank Syariah di Kota Banda Aceh.

5. Hasil penelitian untuk hipotesis keempat diperoleh penjelasan bahwa custumer trust tidak berpengaruh signifikan terhadap customer loyalty pada Bank Syariah di Kota Banda Aceh.

6. Kemudian hasil juga membuktikan bahwa hipotesis kelima terdapat pengaruh customer satisfaction terhadap customer loyalty nasabah Bank Syariah di Kota Banda Aceh.

7. Sedangkan hasil pengujian terhadap hipotesis keenam menunjukkan bahwa terdapat pengaruh direct dan indirectservice quality, custumer trust terhadap customer satisfaction dan berdampak terhadap customer loyalty pada Bank Syariah di Kota Banda Aceh.

\section{DAFTARPUSTAKA}


Arikunto, S.(2006). Metode Penelitian Kuantitatif. Jakarta: PT. Rineka Cipta.

Brown, S.A. (2006). Total Quality Service. Ortario: Prentice Canada Inc.

Cortada, J.W. (2005). Total Quality Manajemen (TQM), terjemahan Eko Suwandi. Yogyakarta: Andi.

Gaspers, V. (2005). Manajemen Kualitas dalam Industri Jasa: Strategi untuk Memenangkan Persaingan Global. Jakarta: PT. Gramedia Pustaka Utama.

Ghozali, I. (2006). Aplikasi Analisis Multivariate dengan program SPSS. Semarang: Badan Penerbit Universitas Dipenogoro.

Gujarati, D. (2006). Ekonometrika Dasar. Jakarta: Erlangga.

Hannah, M. and Peter, K. (2005). Customer Satisfaction: How to Maximaze, Measure and Market Your Company's Ultimate Product. New York: American Management Association

Joseph, A.D. (2007). Bank dan Lembaga Keuangan Lainnya. Jakarta: PT. Raja Grafindo Persada.

Kennet, R. (2006). Expectation Performance Evaluation \& Customeris Perseption of Quality. Jornal Marketing, (Soring).

Kotler, P. (2007). Manajemen Pemasaran: Analisis, Perencanaan, Implementasi, dan Pengendalian, terjemahan. Jakarta: Salemba Empat.

Kotler, P., Swee, H.A., Siwe, M.L., and Cvhin, T.T. (2001). Marketing manajemen: Analysis, Planning; Implementation, and Control, 9 th ed. Englewood Cliffs, N.J.: Prentice Hall International, Inc.

Lupiyoadi, R. (2006). Manajemen Pemasaran Jasa, Edisi Kedua. Jakarta: Salemba Empat.

Malhotra, K.N. (2006). Riset Pemasaran Pendekatan Terapan. Jakarta: PT. Indeks Kelompok Gramedia.

Moeliono. (2007). Manajemen Perbankan. Yogyakarta: BPFE Universitas Gajah Mada.

Mowen. (2005). Marketing dan Perilaku Konsumen. Jakarta: Bandar Maju.

Parasuraman, A., et al. (2005), A Conceptual Model of Service Quality and Its Implecations for Future Reseach. Journal of marketing, Col. 49 (Fall).

Stamatis, D.H. (2006). Total Quality Service, Principles, Practices \& Implementation. Singapore: SSMB Publishing Devision.

Supranto. J. (2006). Pengukuran Kepuasan Konsumen. Jakarta: PT. Rineka Cipta.

Supriyanto, S. (2018). Pengaruh Kinerja Keuangan Terhadap Pendapatan Saham Perbankan Di Bursa Efek Indonesia. Jurnal Bis-A: Jurnal Bisnis Administrasi, 2(1), 39-53.

Suyatno. (2006). Pengantar Ilmu Perbankan. Jakarta: Rineka Cipta.

Tjiptono, F. (2005). Total Quality Manajemen, Edisi Kedua. Yogyakarta: Andi.

Tjiptono, F. (2005). Total Quality Service. Yogyakarta: Andi.

Zeithhami, B. dan Parasuraman. (2006). Service Marketing. New York: The Mc. Graw-Hill Companies, Inc. 
Zikmund, W.G., Raymond, M.J., and Faye, W.G. (2003). Customer Relationship Management: Integrating Marketing Strategy and information technology. Toronto: John Wiley and Sons Inc. 